\title{
Intergenerational Occupational Mobility of Workers in the Traditional Pottery Industries in Kottayam District, Kerala: A Critical Approach
}

\author{
Dr.A. Sumathi and V. Sujadevi
}

\begin{abstract}
Pottery is an age old handicraft in India. It is traced back to the earliest times of civilization. The pottery making traits was beginning back to the Neolithic era. During the times of Indus Valley Civilisation this effective art form was improved with the technology. The Harappan and Mohanjodara Cultures also improved this art with the technology of wheels. Since then these wheels are rolling out the finest pots under the expert hands of the Indian craftsmen.

In recent years the globalisation of the markets and the technological revolution has brought the drastic and rapid changes in the relative importance of the individual sectors and occupations in the Indian economy. This means that more and more people will have to adapt a change of job or career during their working life. Hence most sociological attention is focused on intergenerational occupational mobility in explaining the patterns of occupational attainments on the basis of inter-cohort comparisons. This paper describes patterns of intergenerational occupational mobility of the workers in traditional pottery industries in Kerala and their long term trends of their mobilisation. It also presents the conceptual links between the individual mobility and developments of inequality along with their life course.
\end{abstract}

Keywords--- Traditional Occupation, Intergenerational Occupational Mobility, Pottery Industry.

\section{INTRODUCTION}

$\mathrm{P}$ OTTERY industry is one of the important traditional industries in Kerala, which has grown from the humble beginnings. The principal factors that influence the location of the industry are the availability of essential raw materials, like clay and fire wood and the transportation facilities. This industry provides the ancillary employment from operations such as quarrying, collection and supply of firewood, transportation of pots etc. It had a very interesting birth in India, but now socio-economic conditions of the traditional potters are far from satisfactory. Traditional clay making is the main occupation of the Velaar Community and only a few potters went for the other employments outside their villages. Now they are absorbed in petty business, construction work, minor household industry, government services, private sector companies employment and other manual labours.

Dr.A. Sumathi, Professor, Department of Commerce, Karpagam University, Coimbatore.

V. Sujadevi, Research Scholar, Karpagam University, Coimbatore. DOI:10.9756/BIJIEMS.8300
Mobility

Mobility refers to the movement from one point to another. It is enabled to a varying extent by the economic capital (more income), cultural capital (higher education), human capital (competence and effort in labour), social capital (support from one's social net works), physical capital (ownership of tools or the means of production) and symbolic capital (worth of an official title, status, class, celebrity etc).

Occupational mobility is concerned with the movement or shift from one occupation to another. It denotes the movement or changes in occupation. This may take place in two forms:

1. Inter-generation occupational mobility.

2. Intra-generation occupational mobility.

Inter Generational Occupational Mobility

It refers to the changes in the social status and economic mobility which may occur from one generation to another. Intergenerational mobility can best be determined by analyzing the background of the children who are from the least or most affluent families end up in terms of incomes and start earn as adults. The children's income as adults is compared with their parent's income. The two main determining factors of intergenerational mobility are:

1. The amount of opportunities in society.

2. The rates at which one can increase the economic condition and associate that with the change in the occupational structure.

\section{REVIEW OF LITERATURE}

The literature review of intergenerational occupational mobility shows that many learned educationists and researchers have commented over the occupational and social mobility in the various sectors of society and economy but none has done a detailed study supported by success stories in Kerala, which has been the thrust of present article.

Mehtabul Azam (2013) examined the intergenerational occupation mobility in India among men born during 1945-85 and tried to distinguish between absolute and relative transmission of occupation from father to child in India. He identified that changes in mobility patterns in the long run may result either from an evolution of the economic structure or from changes in the degree of openness of the society.

Majumdar and Kumar (2010) studied the intergenerational occupation mobility in India based upon random sampling of the Indian electorate in 1971 and 2006. They distinguish 
between changes in structure and fluidity and found that the overall probability of occupation switch by next generation relatively increased from 32\% in 1983 to $41 \%$ in 2004-05.

Azam and Bhatt (2013) shared certain literature about the intergenerational occupation mobility of skilled and non skilled father's occupational category and found that the probability that a son would fall in the father's category is higher for low skilled/low paying occupation in India and it is higher in urban areas as compared to rural areas.

Long and Ferrie (2005) examined intergenerational occupation mobility among the agricultural wage workers and farmers. The results showed that this has been increased overtime and the probability of someone born to unskilled workers getting a skilled/semi-skilled job has increased recently.

Featherman and Hauser(1978) looked at intergenerational mobility between various generations and within families. They traced conceptual link between individual mobility and developments of inequality which characterised by specific forms of cumulative advantage and disadvantage.

\section{Statement Of the Problem}

Historically Indian society had been stratified on the caste lines which were initially developed based on the occupation. The studies on intergenerational occupation mobility has been considered relevant per se as societies, where occupation and positions are fixed and set at birth and are transmitted from father to child through rigid schemes, which have little room for innovation. The evolution of income distribution, inequality in income and occupational structure across generation has attracted increasing attention in recent days .It reflects a widely shared views that intergenerational linkages in socio-economic status may result inequality of opportunities in a society.

Pottery industry is one of the important traditional industries in Kerala. Now days the number of potters who can make a living of their occupation has decreased drastically. The reasons for this is mainly due to decline in the availability of raw materials, decrease in demand and increased supply of mass produced industry made potteries. Considering this the traditional potters in Kerala will definitely receive the attention of the scholars. Hence the present study is titled as Analysis and Interpretation of Data "intergenerational occupation mobility of workers in traditional pottery industry" based on Kottayam district, Kerala.

\section{OBJECTIVES OF THE STUDY}

1. To find out the generational shifts in the Traditional Pottery industry in Kerala.

2. To evaluate the influence of education and income in the intergenerational occupational mobility.

3. To examine the reasons for not following or retaining tradition occupation.

4. To identify the feeling of the present job as superior or inferior.

5. To offer the suggestions to improve the traditional pottery industry

\section{RESEARCH METHODOLOGY}

\section{Sampling Method}

An attempt has been made to trace the empirical evidence on the occupational mobility from the grandfather to the fathers, daughters and sons of the potters. In this study 50 occupationally mobilized members in Velaar Community in Kottayam district has been selected for the data collection. To analyse the intergenerational occupational mobility among the Velaar Community the occupation of the four generations are considered in this study ie., the occupation of the first generation- grandparents, second generation, the parents, third generation, the respondents themselves and the fourth generation- the daughters, sons of the respondents. As regards the intergenerational occupational mobility, 50 respondents are selected deliberately. To elicit the views of respondents, they are personally contacted by the researcher with an interview schedule.

\section{Tools for Analysis}

Frequency Tables, Percentage analysis, Ranking methods, $\mathrm{F}$ Test and T-test are used to analyze the collected data.

\section{Hypothesis}

The reasons for not following or retaining the hereditary occupation among the Velaar Community are not significant for the intergenerational occupational mobility.

Table 1: Occupation-wise Classification of Four Generations of respondents

\begin{tabular}{|c|c|c|c|c|c|c|c|c|c|c|c|c|c|}
\hline & 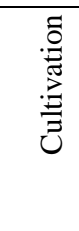 & 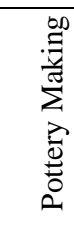 & 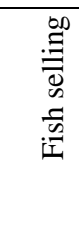 & 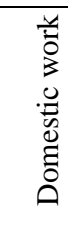 & 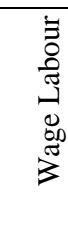 & 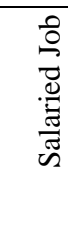 & 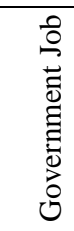 & 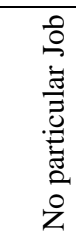 & 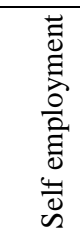 & 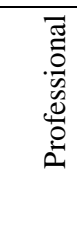 & 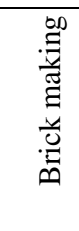 & $\sum_{\bar{\Delta}}^{\grave{\Delta}}$ & 퓽 \\
\hline Maternal Grand Father & & 50 & & & & & & & & & & & 50 \\
\hline Maternal Grand Mother & & 50 & & & & & & & & & & & 50 \\
\hline Wife/husband & & 1 & 1 & 11 & 16 & 5 & 4 & & 3 & 1 & 2 & 1 & \\
\hline Son/daughter & & & & & 7 & 9 & 1 & 1 & 2 & 1 & & 1 & \\
\hline Respondents & & & 5 & & 19 & 13 & 5 & & 4 & & 2 & 2 & 50 \\
\hline
\end{tabular}


The above table provides evidence on the occupational mobility of four generations of the respondents. The traces reveal the occupational mobility among the youngsters belonging to Velaar Community, whose forefathers did traditional pottery making. From the above table it is revealed that $100 \%$ maternal grandparents did traditional pottery making, out of 50 parents only $52 \%$ did it, $36 \%$ are wage labours and the remaining did various other jobs. No one had achieved high occupational status even though they mobilized from pottery making. While analyzing the occupational status of respondents it reveals that $38 \%$ are wage labours, $10 \%$ engaged in fish selling, $4 \%$ are in brick making, $4 \%$ are drivers, $8 \%$ have self employment, $26 \%$ got salaried job and the remaining $10 \%$ positioned in government jobs.

Analysis of occupational status in the four generations are revealed-100\% maternal grandparents did the traditional pottery making, out of 50 parents-only a $52 \%$ did it, $36 \%$ are wage labours and the remaining did various other jobs. No one had achieved a high occupational status even though they mobilized from the pottery making. While analyzing the occupational status of the respondents it reveals that $38 \%$ are wage labours, $10 \%$ engaged in fish selling, $4 \%$ are in brick making, $4 \%$ are drivers, $8 \%$ have self employment, $26 \%$ got salaried job and the remaining $10 \%$ positioned in government jobs.
Analysis on "better job for children" reveals that the children's own interests, increased industrialisation, to derive more income have an equal importance in their mobilisation. "Getting better status" is the least considered one.

Educational achievement is an indicator for the upward intergenerational occupational mobility. Study reveals, the 4th generation could be able to attain a moderate academic qualification.

Income analysis expresses $14 \%$ respondents get below Rs 5000 income, it ranges between Rs. 5000 to 10,000 for $68 \%$, only $18 \%$ obtained above Rs 10,000 income. $84 \%$ respondents expressed as the income is sufficient for them.

While analysing their present occupational status, 54\% felt it is superior to their hereditary occupation, $38 \%$ have the feeling of equal status and only $8 \%$ felt it as inferior.

Less effort, adequate regular income, no risk are the prime reasons for feeling as superior; no freedom in present job, feeling of loss in traditional skill and knowledge, high effort caused inferiority. Results show that $66 \%$ think that the occupational mobility cannot contribute higher status to them, $72 \%$ felt salaried job is not a necessary condition for the occupational status.

\section{Hypothesis Testing}

Table showing reasons for not following the tradition occupation by daughter/son.

\begin{tabular}{|l|l|l|l|l|}
\hline Sl. No. & Reasons & Frequency & Per cent & Rank \\
\hline 1 & Low status & 18 & 36 & 7 \\
\hline 2 & Low income & 47 & 94 & 2 \\
\hline 3 & Casual nature & 37 & 74 & 4 \\
\hline 4 & More educated & 26 & 52 & 6 \\
\hline 5 & Difficult job & 48 & 96 & 1 \\
\hline 6 & High risk & 48 & 96 & 1 \\
\hline 7 & Getting high occupational status & 10 & 20 \\
\hline 8 & High effort & 48 & 96 & 1 \\
\hline 9 & Lack of raw materials & 47 & 94 & 2 \\
\hline 10 & Disinterest & 35 & 70 & 5 \\
\hline 11 & Impossibility of direct selling & 11 & 22 & 8 \\
\hline 12 & Feeling of exploitation by middle men & 11 & 22 & 8 \\
\hline 13 & No opportunity to familiar with traditional occupation & 41 & 82 & 3 \\
\hline 14 & Irregular income & 47 & 94 & 2 \\
\hline
\end{tabular}

\begin{tabular}{|c|c|c|}
\hline Element & F.Value & Sig. Value \\
\hline Age & 1.012 & .416 \\
\hline Education & .632 & .778 \\
\hline Income & .368 & .776 \\
\hline Gender & t-value 1.114 & Sig. Value- .276 \\
\hline
\end{tabular}

$P$ values are significant at $5 \%$ level of significance in the elements like respondent's age and gender. The null hypothesis is rejected at the same time the $\mathrm{P}$ values of the elements like Education and Income level of the respondents are not significant at $5 \%$ level. Hence the hypothesis is accepted.

\section{FINDINGS}

1. Social prestige and status depend upon the occupational status that the individuals are allocated; it can be determined in scaling the occupational hierarchy. There is no significant representation of the youngsters either in government jobs or professional jobs. It reveals that the intergenerational occupational mobility does not result in high socio-economic and 
occupational status to the Velaar community in Kerala.

2. High effort, high risk, difficult job influenced their mobilisation.

3. Getting improved regular income is prime reason for not following or retaining the hereditary occupation.

4. 'Getting the better statuses is also not an important element when they expecting the 'better job for their children'.

5. There is no positive association between the education and mobility in the second and third generation. It seems to be correlated in the fourth generation only.

6. Most of them felt that there is sufficient income from their present occupation as compared to their ancestor's income.

7. All the respondents felt that the occupational status has been improved even though they follow claymaking but it should also bring adequate regular income.

\section{SUGGESTIONS}

1. Inadequate income is the prime element among the workers mobilising traditional industry. This study suggests the raising some forms of government spending will generally narrow the economic inequality that exists in this sector.

2. The structured vocational activities-that are absent now in schools-provide the students to access their traditional skills and knowledge. It will benefit them to develop certain forms of social and cultural capital. Government should initiate to implement such curriculum that allows the inspiring traditional culture and inherent the instincts on potters among the children.

3. Government of India tried to spell out the priority sector since her first industrial policy 1948. Unfortunately so much prestigious Indian traditional industries were basically declined at the end of 20th century. Thus government should pay attention to the growth of the traditional industries-especially pottery making-which were nurtured by the craftsmen as part of their duty towards the society.

4. "Head-Start Assets" refer to the assets that children can inherit from their parents when compared to the individuals who do not have these head-start assets. This is a quick way of identifying the families that might potentially receive, the large enough financial assistance to transform the bio-graphics which can help to improve their class-standing and attain the advantage for at least one child in their family. Velaar community in Kerala can use to give them an advantage of this cultural capital to advance their status in future.

5. Reservation policy in higher education for Velaar community has not a significantly influence in their occupational status. Thus, this study intends to explore the alternative explanation in the subsequent work.

\section{CONCLUSION}

Although this exists in many studies on Indian caste system, only a few has tried to address the intergenerational occupational mobility issues. The past 65 years have been a period of major economic reforms in India. The reforms have unleashed a strong competitive pressure on vast segments in the previously protected economy. This can reduce the caste based discrimination in both the hiring and wages and there by induce a faster rise in the intergenerational occupational mobility of workers in the traditional pottery industry in Kerala.

\section{REFERENCES}

[1] Mehtabul Azam, "Intergenerational Occupational Mobility in India”, IZA DP No. 7608, Oklahama state university, 2013.

[2] Majumdar and Kumar, "Intergenerational mobility and occupational attainment-A comparative study of social class in India", The Journal of Applied Economic Research, Pp.463-494.

[3] Azam and Bhatt, "Intergenerational Educational Mobility in India", IZA DP No. 6549, 2013.

[4] J. Long and J. Ferrie, "Intergenerational occupational mobility in Britain and the US since 1850”, American Economic Review, Vol. 103, No. 4, Pp.1109-1137, 2013.

[5] Featherman and Hauser, "Intergenerational occupational mobility in a rural economy”, Research Paper, George Washington University, 1978. 